\title{
Two Different Pituitary Adenomas in a Patient with Multiple Endocrine Neoplasia Type 1 Associated with Growth Hormone-Releasing Hormone-Producing Pancreatic Tumor: Clinical and Genetic Features
}

\author{
Yasumi SHINTANI, Katsuhiko YOSHIMOTO*, HideAKi HORIE, TOSHIAKI SANO**, \\ YOSHIKO KANESAKI, EMIKO HOSOI, YUTAKA YOKOGOSHI, HIROSHI BANDO, \\ HiROYUKI IWAHANA*, SEIJI KANNUKI***, KEIZO MATSUMOTO***, \\ MitsuO ITAKURA*, AND SHIRO SAITO \\ First Department of Internal Medicine, *Otsuka Department of Clinical and Molecular Nutrition, \\ **Departments of Pathology and ***Neurosurgery, School of Medicine, The University of Tokushima, \\ Tokushima 770, Japan
}

\begin{abstract}
The clinical and genetic features of a 43-year-old male patient with multiple endocrine neoplasia type 1 were reported. He developed hyperparathyroidism, a GHRH-producing pancreatic tumor, and acromegaly between 1980 and 1983. Because his pituitary gland increased in size even after resecting the GHRH-producing pancreatic tumor, transsphenoidal hypophysectomy was performed six years later. The pituitary contained two histologically-different adenomas composed of somatotroph cells and null cells. Genetic analyses revealed loss of heterozygosity on chromosome 11 in common in the pituitary adenomas, the pancreatic endocrine tumors, and a parathyroid hyperplasia. On the other hand, mutations of ras, p53, Gs $\alpha$, and Gi2 $\alpha$ genes were not found in these tumors. The loss of the tumor suppressor gene on chromosome 11q12-13 was involved in the formation of two pituitary adenomas, two pancreatic endocrine functioning tumors, and a parathyroid hyperplasia in this patient, but the tumorigenic factors in the specific endocrine organs remain to be studied.
\end{abstract}

Key words: MEN 1, Pituitary adenoma, Ectopic GHRH-producing tumor, Loss of heterozygosity, Chromosome 11

(Endocrine Journal 42: 331-340, 1995)

MULTIPLE endocrine neoplasia (MEN) is characterized by hyperplasia or neoplasia arising from multiple endocrine organs and classified into types $1,2 \mathrm{~A}$, and $2 \mathrm{~B}$ according to the combination of affected endocrine organs. Familial MEN 1 is inherited as an autosomal dominant trait and affects specific endocrine organs in the combination of the parathyroid, the pancreatic islet and the pi-

\section{Received: September 13, 1994}

Accepted: December 19, 1994

Correspondence to: Dr. Yasumi SHINTANI, The First Department of Internal Medicine, School of Medicine, The University of Tokushima, 3-18-15 Kuramoto-cho, Tokushima 770, Japan tuitary.

The syndrome of MEN 1 is believed to be caused by a mutation or deletion in the MEN1 gene on chromosome 11q12-13 [3]. The inactivation of the MEN1 gene in MEN 1-associated tumors can be demonstrated by loss of heterozygosity (LOH) at the MEN1 locus, which is localized between PYGM and D11S146 on 11q12-13 [4]. Common LOH on chromosome 11 has been found in pancreatic and parathyroid tumors in MEN 1 patients [3-9], but few studies have been made on the LOH in MEN 1-associated pituitary tumors. Although $\mathrm{LOH}$ on chromosome 11 was not found in one MEN 1-associated pituitary adenoma by Byström et al. [4], 
we previously reported $\mathrm{LOH}$ on chromosome 11, including loci of D11S149, HRAS1 and F2 in one familial MEN 1-associated pituitary adenoma secreting both GH and PRL [10]. Recently, Thakker et al. reported another case of $\mathrm{LOH}$ on $11 \mathrm{q}$ in a somatotroph cell adenoma from one MEN 1 patient [11].

We examined a male patient with familial MEN 1 associated with parathyroid hyperplasia, GHRHsecreting pancreatic tumor and acromegaly. His clinical and pathological features before and one year after surgery were reported previously [12, 13]. We also reported that $\mathrm{LOH}$ was detected in pancreatic tumors from this patient [5]. The plasma GHRH level was normalized after resecting the pancreatic tumor, but transsphenoidal hypophysectomy was performed since the plasma GH level and pituitary size gradually increased.

To clarify the relationship between an ectopic GHRH-secreting tumor and pituitary pathology, and to investigate the genetic abnormalities related to tumorigenesis in specific endocrine organs, we carried out endocrine and pathological studies as well as genetic analyses of the tumors. We report herein the results of endocrine studies, pathology of the pituitary adenomas, common $\mathrm{LOH}$ in tumors in three different endocrine organs, and the absence of mutations of other examined oncogenes.

\section{Materials and Methods}

\section{Case report}

A 43-yr-old man was admitted to our hospital in September, 1992 for evaluation of his pituitary mass and acromegaly. He was diagnosed in 1980 as having primary hyperparathyroidism. Parathyroidectomy was performed three times between 1980 and 1983 and hypercalcemia was corrected. In 1983, acromegalic features became prominent and skull $X$-ray films showed an enlarged sella turcica. In addition, abdominal CT revealed a tumor mass in the tail of the pancreas. His father had Cushing's disease and primary hyperparathyroidism, and his younger sister had prolactinoma and primary hyperparathyroidism. Based on the clinical findings and family history, he was diagnosed as MEN 1.

Increased plasma GHRH was found in 1986, sug- gesting an ectopic GHRH-secreting tumor in the pancreas. Laparotomy was performed, and both a large and a small tumor were enucleated from the pancreas. The larger tumor weighing $30 \mathrm{~g}$ was immunohistologically stained with the antibodies for GHRH, somatostatin and calcitonin. The smaller one was stained with those for glucagon and pancreatic polypeptide (PP) [12, 13]. After surgery, the plasma GHRH level decreased to the normal value. The plasma GH level also decreased, but remained higher than normal. Evaluation of the pituitary by magnetic resonance imaging (MRI) was repeated four times and it was shown that the pituitary mass had slowly enlarged in size.

In November, 1992, the pituitary tumor was resected by transsphenoidal surgery. The postoperative course has been satisfactory.

\section{Endocrine studies}

The materials and methods for endocrine studies were previously reported in detail [12]. Plasma $\mathrm{GH}$ before and after a provocative test or a suppressive test was assayed by RIA [12]. Plasma GHRH was assayed as reported previously [14, 15]. Data were presented as means $\pm S D$ with the number of samples shown as ' $n$ '.

\section{Pathological evaluation}

A number of tumor pieces were obtained for pathological studies by means of a light microscopy and immunohistochemistry according to the methods described previously [16].

\section{DNA extraction}

The pituitary tumor was kept frozen at $-70{ }^{\circ} \mathrm{C}$ until analysis. DNA isolation was performed by a standard method of phenol-chloroform extraction. Leukocyte DNA from the patient was used as a control to study the $\mathrm{LOH}$ in the tumor tissue DNA. Genomic DNAs of the two different pituitary adenomas and the parathyroid hyperplasia were separately extracted from each tissue embedded in paraffin as previously described [17].

\section{Southern blot analysis}

Approximately $10 \mu \mathrm{g}$ of DNAs extracted from the tumors and leukocytes were digested with sev- 
eral restriction enzymes. The resulting fragments were separated by agarose gel electrophoresis and transferred to nitrocellulose membrane by Southern blotting. Hybridization, labeling of probes, and autoradiography were performed according to the standard procedures previously described [5].

\section{Detection of LOH by using microsatellite polymorphisms}

Four microsatellite loci of PYGM (CA) (GA) repeat [18], D11S534 [19], D11S527 [20], and CD3D [21] were used in this study. One of each oligonucleotide primer pair was labeled with FAM fluorescent dye (Perkin Elmer, Foster City, CA). Polymerase chain reaction (PCR) was performed with a thermal cycler (Astec, Fukuoka, Japan) with $50 \mathrm{ng}$ of genomic DNA as a template in a total volume of $10 \mu l$ [22]. Twenty-five cycles consisting of $1 \mathrm{~min}$ at $95^{\circ} \mathrm{C}$ for denaturation, $1 \mathrm{~min}$ at 60 ${ }^{\circ} \mathrm{C}$ for annealing and $2 \mathrm{~min}$ at $72{ }^{\circ} \mathrm{C}$ for extension were performed. For gel analysis, $0.5 \mu$ of internal lane standards (Gene Scan 2500-Rox, Perkin Elmer), $2 \mu l$ of PCR products and $4 \mu l$ of formamide were combined. Specimens were heated to $95^{\circ} \mathrm{C}$ for $4 \mathrm{~min}$ immediately prior to gel loading. Gels consisted of $6 \%$ acrylamide with $8 \mathrm{M}$ urea in $90 \mathrm{mM}$ Tris-borate ( $\mathrm{pH} 8.3$ ) and 2 mM EDTA. Gel electrophoresis, data collection and analysis were performed on a Model 373A DNA sequencer with GENESCAN 672 software (Perkin Elmer, division of Applied Biosystems) [23].

\section{Screening of mutations of the $p 53$ and ras genes by PCR-SSCP}

Mutations in exons 5 to 10 of the p53 gene, and exons 1 and 2 of the $\mathrm{H}-, \mathrm{K}-, \mathrm{N}$-ras genes were analyzed by PCR-SSCP as previously described [24, 25].

Detection of mutations of codons 201 and 227 of the Gs $\alpha$ gene by direct sequencing of genomic DNA

A pair of primers, flanking codons 201 and 227 of the Gs $\alpha$ gene, were used to generate a single specific amplification product from each specimen. The nucleotide sequence of the primers contained at their $5^{\prime}$ ends the additional sequence of a universal or a reverse M13 sequence of [ $5^{\prime}-T G$ -
TAAAACGACGGCCAGTGGTGAGATCCATTGACCTCA-3' (italic: a $21 \mathrm{M} 13$ sequence)] and [5'-CAAGAAACAGCT ATGACCCCAAGCCCACAGCATCCTAC-3' (italic: an M13 reverse sequence)] [26]. The method for direct sequencing of the PCR products by an automated DNA sequencer was described previously [24, 25].

Detection of mutations of codons 179 and 205 of the Gi2 $\alpha$ gene by direct sequencing of genomic DNA

A pair of primers (5'-CCCCCCATCCCCAGCTACCT-3' and 5'-TCTCACCATCTCCTCGTCCTC3') flanking codons 175 and 205 of Gi2 $\alpha$ gene [27] were used to obtain DNA templates for direct sequencing. The method for conventional direct sequencing of the PCR products with radioisotopes was described previously [28].

\section{Results}

\section{Endocrine studies}

In 1980, the plasma GH of the patient was already slightly increased to $7.0 \pm 1.2 \mathrm{ng} / \mathrm{ml}(\mathrm{n}=3$; normal, $<5$ ). The plasma PRL was $3.4 \mathrm{ng} / \mathrm{ml}$ (normal, 1.1-9.8). A paradoxical rise in plasma GH after TRH (peak $34 \mathrm{ng} / \mathrm{ml}$ at $15 \mathrm{~min}$ ) or oral glucose load (16 $\mathrm{ng} / \mathrm{ml}$ at $180 \mathrm{~min}$ ) was observed. Plasma GHRH in 1983, which was retrospectively evaluated with frozen plasma samples, was increased to $360 \mathrm{pg} / \mathrm{ml}$ (normal, $10.4 \pm 4.1$ ). Re-examination in 1985 by the TRH test confirmed a paradoxical release of $\mathrm{GH}$. The plasma GHRH was $299 \pm 61 \mathrm{pg} / \mathrm{ml}(\mathrm{n}=16)$ in 1985 to 1986 before resecting pancreatic tumors, which was accompanied by increased plasma GH $(42.4 \pm 31.3 \mathrm{ng} / \mathrm{ml}$, $\mathrm{n}=16$ ). After resection of the pancreatic tumors, the plasma GHRH level decreased to within the normal range, while the plasma GH level remained high $(9.8 \pm 3.8 \mathrm{ng} / \mathrm{ml}, \mathrm{n}=8)$. Before resection of the pancreatic tumors, exogenous GHRH (100 $\mu \mathrm{g}$, iv) increased plasma GH (peak $205 \mathrm{ng} / \mathrm{ml}$ at $15 \mathrm{~min}$ ), and octreotide acetate (100 $\mu \mathrm{g}, \mathrm{sc})$ suppressed GH secretion. After resection of the pancreatic tumors, the plasma GH increased in response to exogenous GHRH, but the magnitude of the increase was considerably smaller than that before surgery. The response of plasma GH to TRH or glucose was no longer observed after resection of the 
GHRH-secreting pancreatic tumor.

During the 3 years after resection of the pancreatic endocrine tumors, the pituitary mass did not apparently increase in size in spite of the high plas$\mathrm{ma}$ GH $(9.3 \pm 2.7 \mathrm{ng} / \mathrm{ml}, \mathrm{n}=21)$ in 1986-1988. More recently, since 1989, baseline plasma GH gradually increased $(13.0 \pm 2.2 \mathrm{ng} / \mathrm{ml}, \mathrm{n}=9$ in $1989,15.0 \pm$ $5.4 \mathrm{ng} / \mathrm{ml}, \mathrm{n}=26$ in $1990,18.2 \pm 2.6 \mathrm{ng} / \mathrm{ml}, \mathrm{n}=11$ in 1991) in spite of the normal plasma GHRH, and acromegalic features became more prominent than before. In 1992, plasma $G H$ was $15.9 \pm 3.9 \mathrm{ng} / \mathrm{ml}$ $(\mathrm{n}=11)$ and plasma IGF-I was $462 \mathrm{ng} / \mathrm{ml}$ (normal, 100-250) before the transsphenoidal surgery. In addition, MRI showed that the pituitary mass had gradually increased in size between 1989 and 1992 (Fig. 1). It was found only after histological analysis of the resected tumor that he had two different pituitary adenomas. After resection of the pituitary tumors, the high plasma $G H$ reverted to normal $(2.1 \pm 0.9 \mathrm{ng} / \mathrm{ml}, \mathrm{n}=7)$.

\section{Pathological findings}

Morphological examination revealed that the re-

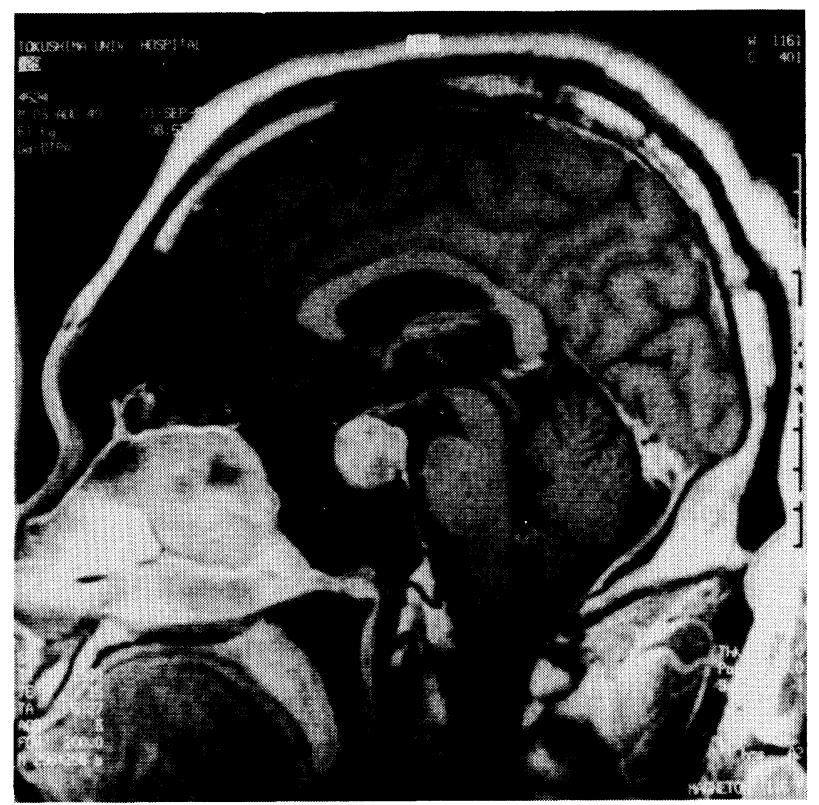

Fig. 1. T1-weighted MR image after gadolinium-DTPA enhancement performed in September, 1992. This reveals a remarkable enlargement of a pituitary gland with heterogeneous internal intensity, suggesting the presence of a pituitary adenoma. sected pituitary tumors were composed of two different adenomas with distinct histological and immunohistochemical features (Fig. 2). The major characteristics of these two adenomas are summarized in Table 1 . One showed diffuse proliferation of mixed eosinophilic and chromophobic cells which contained pleomorphic nuclei and prominent nucleoli. Immunohistochemical studies showed that adenoma cells were positive for GH among 7 adenohypophysial hormones studied. Intracytoplasmic cytokeratin distribution was perinuclear in pattern, suggesting a GH-producing

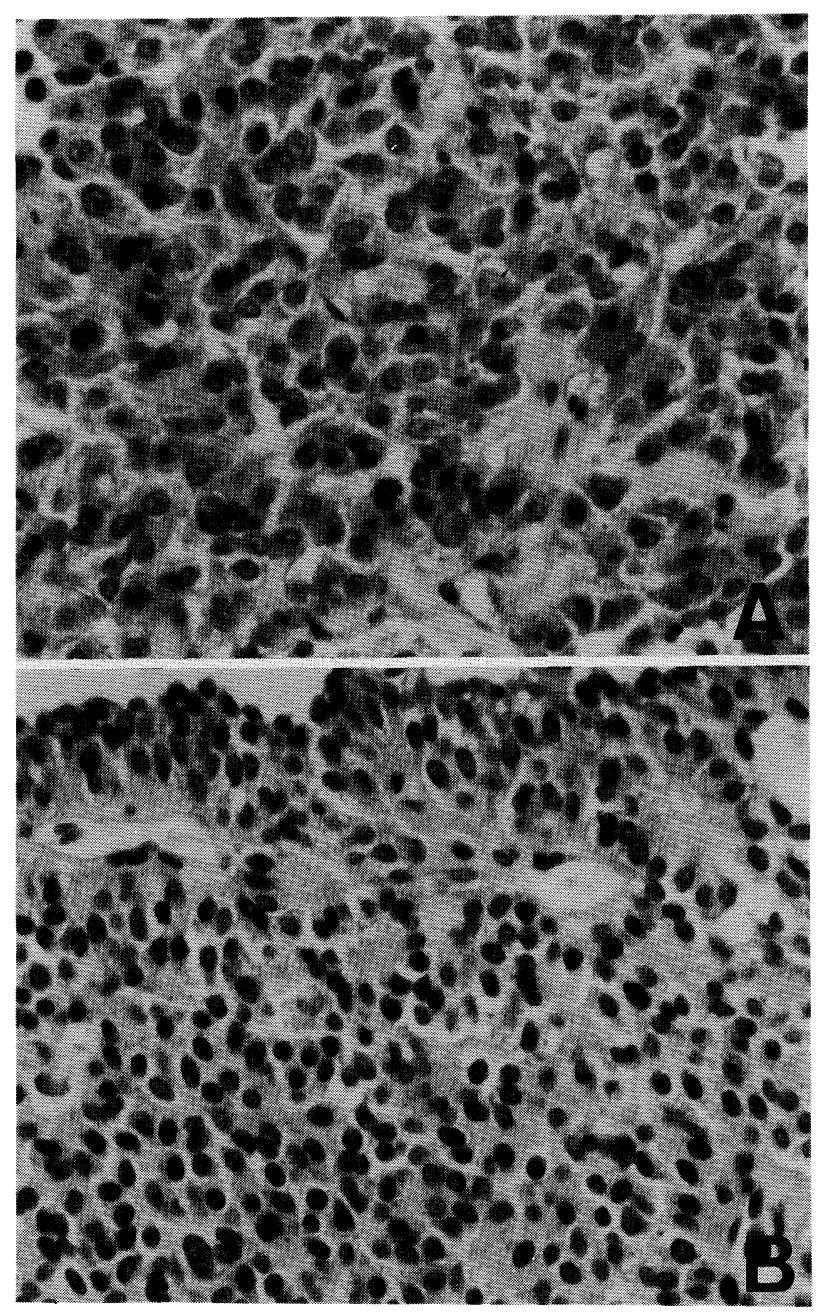

Fig. 2. Microscopic appearance of two different pituitary adenomas. A. Somatotroph cell adenoma. Adenoma cells show signs of anisokaria and have prominent nucleoli. B. Null cell adenoma. Tumor cells with uniform and compact nuclei proliferate in a diffuse or papillary arrangement. (hematoxylin and eosin, $\times 400$ ). 
Table 1. Histological features of two different pituitary adenomas

\begin{tabular}{|c|c|c|}
\hline & GH cell adenoma & Null cell adenoma \\
\hline $\begin{array}{l}\text { Hematoxylin-eosin } \\
\text { staining }\end{array}$ & $\begin{array}{l}\text { mixed eosinophilic } \\
\text { and chromophobic }\end{array}$ & chromophobic \\
\hline Proliferation pattern & diffuse & diffuse and papillary \\
\hline Nuclei & $\begin{array}{c}\text { pleomorphic } \\
\text { prominent nucleoli }\end{array}$ & uniform \\
\hline $\begin{array}{l}\text { Immunohistochemistry } \\
\text { GH }\end{array}$ & positive & negative \\
\hline $\begin{array}{l}\alpha \text {-subunit of } \\
\text { glycoprotein hormone }\end{array}$ & negative & positive (a few cells) \\
\hline $\begin{array}{l}\mathrm{PRL}, \mathrm{ACTH}, \mathrm{FSH} \beta \\
\mathrm{LH} \beta, \mathrm{TSH} \beta\end{array}$ & negative & negative \\
\hline Cytokeratin & $\begin{array}{c}\text { positive } \\
\text { (perinuclear distribution) }\end{array}$ & negative \\
\hline
\end{tabular}

adenoma which lacks fibrous bodies [16]. Another was a chromophobic adenoma composed of cells with uniform nuclei which were smaller than GH-producing adenomas. Focal perivascular pseudorossette formation was noted. A few cells were positive for an $\alpha$-subunit of glycoprotein hormones, but negative for $\mathrm{GH}$ and cytokeratin. Thus the second adenoma was diagnosed as a null cell adenoma. Both adenomas were negative for PRL, $\mathrm{ACTH}, \mathrm{FSH} \beta, \mathrm{LH} \beta$ and TSH $\beta$. In the fragments of non-tumorous adenohypophysial tissue, nearly $80 \%$ of the cells were positive for $\mathrm{GH}$, but reticulin fiber stain showed the preservation of normal architecture. It was uncertain whether this GH-rich portion was a GH-cell hyperplastic area or an area where GH cells were normally abundant.

\section{LOH on chromosome 11}

Restriction fragment length polymorphisms of the leukocyte- and tumor-DNAs were compared for chromosome 11 markers. The LOH on chromosome 11 in the pituitary adenomas was identified by Southern blot analysis with DNA probes, HRAS1, CALCA,D11S151 and D11S146 (Fig. 3, Table 2).

The $\mathrm{LOH}$ was also detected by microsatellite polymorphism analysis on the PYGM locus (Fig. 4, Table 2). His leukocytes on panel A showed the amplification of two distinct clusters of fragments, with major peaks at 186 and 176 nucleotides in size, and the second major peaks at 184 and 174 nucleotides, respectively. The third peaks at 182 and 172 nucleotides were also visible. These minor peaks 2 or 4 nucleotides smaller than the major peaks were due to polymerase skipping [23]. The pituitary adenomas, two pancreatic tumors and parathyroid hyperplasia on panels B, C, D and E showed similar LOH on the PYGM locus. In addition, $\mathrm{LOH}$ of the loci was also observed for D11S534, D11S527, and CD3D in the pituitary adenomas and the GHRH-producing pancreatic tumor, and for D11S527 in the parathyroid hyperplasia, but LOH in the loci of D11S534 and D11S527 was not observed in the glucagon and PP-producing pancreatic tumor (data not shown).

It was impossible to discern by conventional Southern blotting analysis whether this $\mathrm{LOH}$ derives from the somatotroph adenoma, the null cell adenoma or both, because a very small amount of DNA could be extracted from several pieces of tumor tissue obtained by transsphenoidal surgery. However, LOH of the loci of PYGM and D11S527 was commonly detectable in both the somatotroph adenoma and null cell adenoma by PCR-based microsatellite polymorphism analysis of DNA extracted from paraffin-embedded specimens of pituitary adenomas (data not shown).

We previously reported the loss of the common alleles in Southern blot analysis with D11S151 and 


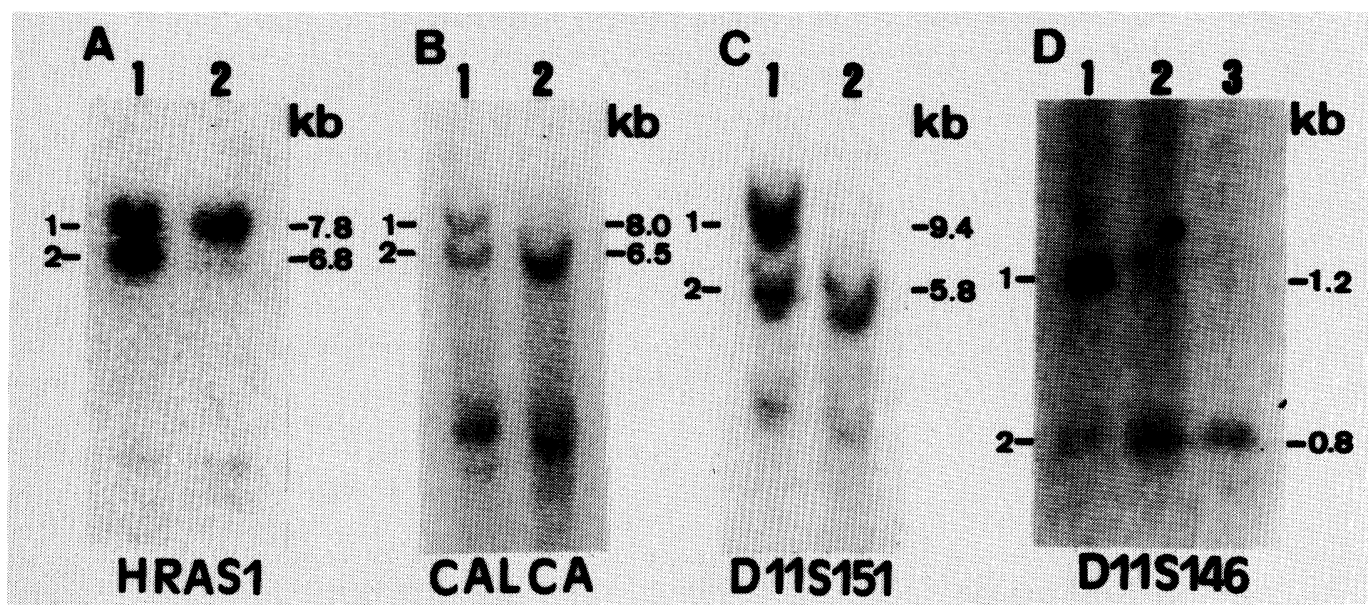

Fig. 3. Loss of heterozygosity at loci on chromosome 11 in the pituitary adenoma and the GHRHproducing pancreatic tumor. The DNA of two tumors and peripheral leukocytes from the patient was digested with appropriate restriction enzymes. Lane 1 shows the digests of DNA from peripheral leukocytes. Lanes 2 and 3 show the digests of DNAs from the pituitary adenomas and a GHRH-producing pancreatic tumor, respectively. Numerals 1 and 2 on the left indicate the alleles observed.

Table 2. Loss of heterozygosity for informative loci in pituitary adenomas, pancreatic tumors and a parathyroid hyperplasia

\begin{tabular}{|c|c|c|c|c|c|c|c|}
\hline \multirow{2}{*}{ Locus } & \multirow{2}{*}{ Location } & \multirow{2}{*}{ Probe } & \multirow{2}{*}{ Enzyme } & \multicolumn{4}{|c|}{ Tumor* } \\
\hline & & & & 1 & 2 & 3 & 4 \\
\hline HRAS1 & $11 \mathrm{p} 15.5$ & pNCO101 & Bam $\mathrm{HI}$ & $\bigcirc$ & 0 & $\bigcirc$ & - \\
\hline PTH & $11 \mathrm{p} 15.2-\mathrm{p} 15.1$ & pPTHm122 & PstI & $\bigcirc$ & $\bigcirc$ & 0 & - \\
\hline$C A L C A$ & $11 \mathrm{p} 15.2-\mathrm{p} 15.1$ & pTT42 & TaqI & 0 & $\bigcirc$ & 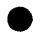 & - \\
\hline D11S151 & $11 \mathrm{p} 13$ & p56H2.4 & PstI & $\bigcirc$ & 0 & 0 & - \\
\hline PYGM & $11 q 12-q 13.2$ & Dinucleotide Repeats & & $\bigcirc$ & 0 & $\bigcirc$ & $\mathrm{O}$ \\
\hline D11S146 & $11 \mathrm{q} 12-\mathrm{q} 13.2$ & pHB159 & TaqI & $\bigcirc$ & O & - & - \\
\hline D11S534 & $11 \mathrm{q} 13$ & Dinucleotide Repeats & & $\bigcirc$ & 0 & 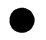 & - \\
\hline D11S527 & $11 \mathrm{q} 13.5$ & Dinucleotide Repeats & & 0 & 0 & 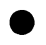 & 0 \\
\hline$C D 3 D$ & $11 \mathrm{q} 23$ & Dinucleotide Repeats & & $\bigcirc$ & $\bigcirc$ & - & - \\
\hline
\end{tabular}

*1, pituitary adenomas; 2 , a GHRH-producing pancreatic tumor; 3 , a glucagon and PP-producing pancreatic tumor; 4 , a parathyroid hyperplasia. $\bigcirc$, loss of heterozygosity; retained heterozygosity; -, not done.

HRAS1 markers in two pancreatic tumors from this patient [5], but the informative polymorphic markers on the long arm of chromosome 11 were not available at that time. In the present analysis, including microsatellite analysis, the loci of D11S146, PYGM, D11S534, D11S527 and CD3D of the patient were shown to be informative, and $\mathrm{LOH}$ in these loci were detected in the GHRH-producing pancreatic tumor (Fig. 3D, Fig. 4C, and Table 2). Because of the $\mathrm{LOH}$ in the loci of $11 \mathrm{p}$ and $\mathrm{q}$ both in the GHRH-producing pancreatic tumor and the pituitary adenomas, extensive loss of chromosome 11 probably exists in these tumors arising from two separate endocrine organs. Table 2 summarizes the results of the genetic analysis of MEN 1-associated tumors of this patient with chromosome 11 markers, which demonstrate that $\mathrm{LOH}$ on chromosome 11 is a common mechanism in the monoclonal development of pancreatic endocrine tumors, pituitary adenomas, and parathyroid hyperplasia in this patient with MEN 1. 


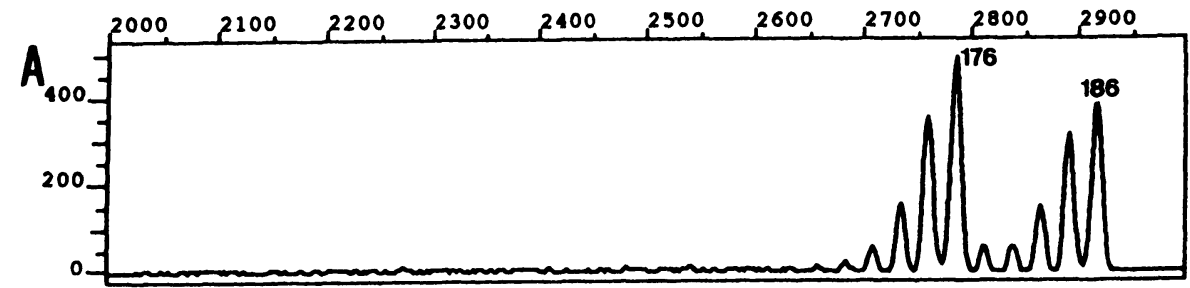

Lane 1: WBC

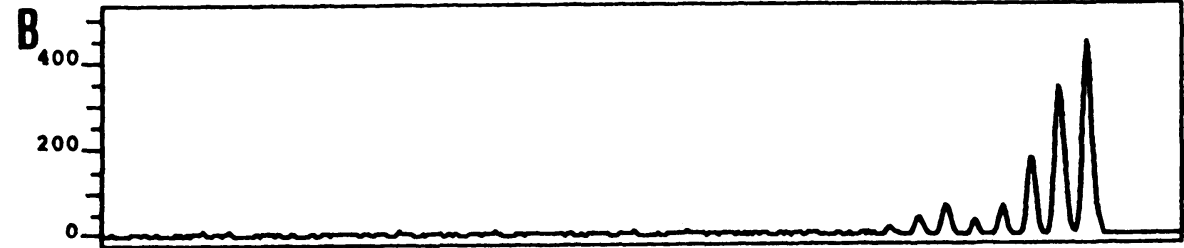

Lane 3: pituitary adenoma

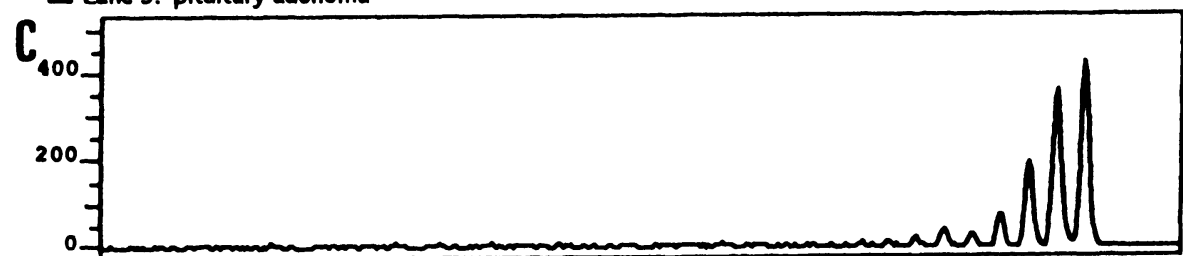

Lane 5: GHRH-producing pancreatic tumor

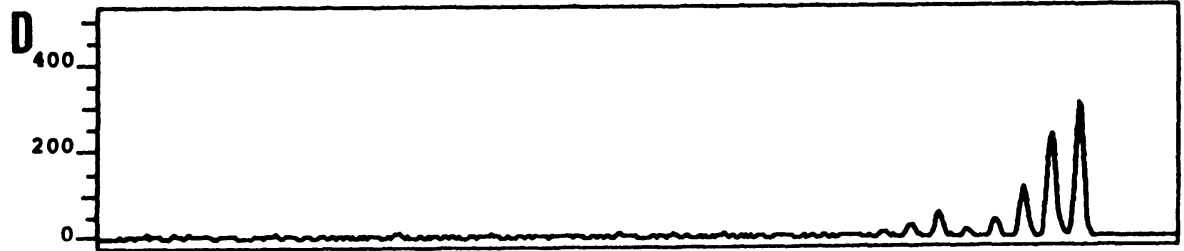

Lane 7: glucagon, PP-producing pancreatic tumor

E

(1)

8001

400

7

Lane 24: parathyroid hyperplasia

Fig. 4. Electrophoretogram display of PCR products of PYGM (CA) (GA) repeat for leukocytes (A), the pituitary adenomas (B), the GHRH-producing pancreatic tumor (C), the glucagon and PP-producing pancreatic tumor (D), and parathyroid hyperplasia (E). The ordinate represents fluorescence signal intensity and the abscissa represents the scan number of band detection from the start of electrophoresis. Fragment size estimates are indicated above each major peak in panel A.

Analyses of mutations of the ras and p53 genes

No mutations were detected by PCR-SSCP in exons 1 and 2 of the $\mathrm{H}_{-}, \mathrm{K}-$, and $\mathrm{N}$-ras genes or in exons 5 to 10 of the p53 gene in the pituitary adenomas, two pancreatic tumors or parathyroid hyperplasia (data not shown).

\section{Analyses of mutations of the Gs $\alpha$ and Gi2 $\alpha$ genes}

Direct sequencing of the Gs $\alpha$ gene in each of the two pituitary adenomas (a somatotroph cell adenoma and a null cell adenoma), two pancreatic tumors, and parathyroid hyperplasia revealed no mutations of codons 201 and 227. No mutations of 
codons 179 or 205 of the Gi2 $\alpha$ gene were found in these tumors (data not shown).

\section{Discussion}

Multiple specific endocrine organs are affected in MEN 1 patients. Hyperplasia or multiple neoplasias are observed in the parathyroid glands and the pancreas, but multiple pituitary tumors are extremely rare in MEN 1. Lips et al. reported multiple pituitary tumors in MEN 1, but did not describe their histologies [29]. According to Scheithauer et al., only one out of 40 patients with MEN 1 exhibited multiple microadenomas consisting of corticotroph cell adenoma and prolactinoma [30]. In our case, two histologically-different pituitary adenomas were found; one was a somatotroph cell adenoma and another was a null cell adenoma.

It is noteworthy that the pituitary adenomas in this patient became apparent 6 years after resecting the GHRH-producing pancreatic tumor. In almost all acromegalic patients with GHRH-secreting tumors, including our patient, plasma GH was either non-suppressed or paradoxically increased by an oral glucose load or by TRH administration. The paradoxical responses usually reverted to normal after resection of the ectopic source of GHRH [31], indicating that the paradoxical rise in plasma $\mathrm{GH}$ was induced by the priming effect of GHRH. In our patient, we suspected a somatotroph cell adenoma or hyperplasia firstly because of slightly increased plasma GH even after resecting the GHRH-secreting pancreatic tumor, and secondly because of the disappearance of the paradoxical rise in plasma $\mathrm{GH}$ in response to TRH or glucose after surgery. The possibility of somatotroph cell hyperplasia was also considered, because 8 out of 9 patients with ectopic GHRH-secreting tumor were reported to have pituitary hyperplasia [1], but one patient was reported to have a pituitary adenoma [32]. In transgenic mice expressing the hGHRH gene, hyperplasia of pituitary somatotrophs, lactotrophs and mammosomatotrophs developed by 8 months of age, and GH- and PRL-immunoreactive adenomas developed at 10-24 months of age $[33,34]$. These findings suggest that prolonged GHRH secretion from the pancreatic tumor plays a certain role in adenoma formation in the pituitary gland.

Another important factor in adenoma formation in the pituitary in our patient is the inactivation of the MEN1 gene. The fact that $\mathrm{LOH}$ on chromosome 11 was found in pituitary adenomas as well as pancreatic endocrine tumors and parathyroid hyperplasia in our patient and a report of another pituitary adenoma in an MEN 1 patient with a GHRH-secreting pancreatic tumor [32] indicates that the somatotroph adenoma and null cell adenoma in our patient arose in the common basis of the inactivated MEN1 gene. To our knowledge, this is the first case of common $\mathrm{LOH}$ on chromosome 11 in tumors in three separate endocrine organs in an MEN 1 patient.

The molecular pathogenesis of MEN 1 should also explain the lapse in time between birth and the development of neoplasia, as well as the cellular pathology, tissue specificity, and variable manifestations among kindred. The finding that a similar LOH occurred even in hyperplastic pancreatic tissue as well as insulinoma [3] suggested that $\mathrm{LOH}$ can occur even during hyperplasia and further transformation to insulinoma was caused by other genetic alterations. In familial polyposis coli, colon cancer arises as a result of inherited mutation of the APC gene and/or such somatic mutations as the ras, and p53 genes [35]. In addition, the mutation in the Gs $\alpha$ gene was found in $40 \%$ of pituitary somatotroph adenomas [17], although the incidence of Gs $\alpha$ gene mutations in GH-secreting pituitary adenomas in Japanese patients with acromegaly was low [36, 37], including one pituitary adenoma in one MEN 1 patient [28], but we detected no mutations in the ras or p53 genes in tumors from 5 MEN 1 patients including this patient. Accordingly, genes other than the ras, p53 or Gs $\alpha$ gene are presumably involved in tumorigenic steps in MEN 1. We found a point mutation of codon 201 of the Gs $\alpha$ gene in only one pituitary adenoma, and not in the parathyroid or pancreatic tumors of one MEN 1 patient [28], implying that a point mutation of the Gs $\alpha$ gene might have worked as a pituitary-specific tumorigenic factor. However, no mutation of codon 201 or 227 of the Gs $\alpha$ gene was detected in pituitary adenomas from our patient and five other MEN 1 patients we reported earlier [37], suggesting that this mutation is not a major organ-specific tumorigenic factor in MEN 1. Organ-specific gene mutations for tumorigenesis in MEN 1, if any, should therefore be identified in the future, in addition to the identification of the actual MEN1 gene and its pro- 
tein product.

\section{Acknowledgments}

This work was supported in part by a Grant-in-
Aid for Scientific Research (No. 02454509) from the Ministry of Education, Science and Culture of Japan and by a grant from Otsuka Pharmaceutical Factory Inc. for Otsuka Department of Clinical and Molecular Nutrition, School of Medicine, The University of Tokushima.

\section{References}

1. Sano T, Asa SL, Kovacs K (1988) Growth hormone-releasing hormone-producing tumors: clinical, biochemical, and morphological manifestations. Endocr Rev 9: 357-373.

2. Price DE, Absalom SR, Davidson K, Bolia A, Bell PRF, Howlett TA (1992) A case of multiple endocrine neoplasia: hyperparathyroidism, insulinoma, GRF-oma, hypercalcitonaemia and intractable peptic ulcer. Clin Endocrinol 37: 187-188.

3. Larsson C, Skogseid B, Öberg K, Nakamura Y, Nordenskjöld M (1988) Multiple endocrine neoplasia type 1 gene maps to chromosome 11 and is lost in insulinoma. Nature 332: 85-87.

4. Byström C, Larsson C, Blomberg C, Sandelin K, Falkmer U, Skogseid B, Öberg K, Werner S, Nordenskjöld (1990) Localization of the MEN1 gene to a small region with chromosome $11 \mathrm{q} 13$ by deletion mapping in tumors. Proc Natl Acad Sci USA 87: 1968-1972.

5. Yoshimoto $K$, Iizuka M, Iwahana H, Yamasaki R, Saito H, Saito S, Sekiya T (1989) Loss of the same alleles of HRAS1 and D11S151 in two independent pancreatic cancers from a patient with multiple endocrine neoplasia type 1. Cancer Res 49: 2716-2721.

6. Friedman E, Sakaguchi K, Bale AE, Falchetti A, Streeten E, Zimering MB, Weinstein LS, McBride WO, Nakamura Y, Brandi ML, Norton JA, Aurbach GD, Spiegel AM, Marx SJ (1989) Clonality of parathyroid tumors in familial endocrine neoplasia type 1. N Engl J Med 321: 213-218.

7. Thakker RV, Bouloux P, Wooding C, Chotai K, Broad PM, Spurr NK, Besser GM, O'Riordan JLH (1989) Association of parathyroid tumors in multiple endocrine neoplasia type 1 with loss of alleles on chromosome 11. N Engl J Med 321: 218-224.

8. Radford DM, Ashley SW, Wells Jr SA, Gerhard DS (1990) Loss of heterozygosity of markers on chromosome 11 in tumors from patients with multiple endocrine neoplasia type 1. Cancer Res 50: 65296533.

9. Bale AE, Norton JA, Wong EL, Fryburg JS, Maton PN, Oldfield EH, Streeten E, Aurbach GD, Brandi ML, Friedman E, Spiegel AM, Taggart RT, Marx SJ (1991) Allelic loss on chromosome 11 in hereditary and sporadic tumors related to familial multiple endocrine neoplasia type 1. Cancer Res 51: 11541157.

10. Yoshimoto $\mathrm{K}$, Iwahana $\mathrm{H}, \mathrm{Kubo} \mathrm{K}$, Saito S, Itakura M (1991) Allele loss on chromosome 11 in a pituitary tumor from a patient with multiple endocrine neoplasia type 1. Jpn J Cancer Res 82: 886-889.

11. Thakker RV, Pook MA, Wooding C, Boscaro M, Scanarini M, Clayton RN (1993) Association of somatotrophinomas with loss of alleles on chromosome 11 and gsp mutations. J Clin Invest 91: 2815-2821.

12. Yamasaki R, Saito H, Sano T, Kameyama K, Yoshimoto K, Hosoi E, Matsumura M, Harada K, Saito S (1988) Ectopic growth hormone-releasing hormone $(\mathrm{GHRH})$ syndrome in a case with multiple endocrine neoplasia type 1. Endocrinol Japon 35: 97-109.

13. Sano T, Yamasaki R, Saito H, Hirose T, Kudo E, Kameyama K, Hiraishi K, Saito S, Hizawa K (1987) Growth hormone-releasing hormone (GHRH)-secreting pancreatic tumor in a patient with multiple endocrine neoplasia type 1. Am J Surg Pathol 11: 810-817.

14. Saito H, Saito S, Yamasaki R, Hosoi E (1984) Clinical value of radioimmunoassay of plasma growth hormone-releasing factor. Letter Lancet 2: 401-402.

15. Zhang C, Yamasaki R, Mitsuhashi S, Takahashi H, Bando H, Saito S (1991) Radioimmunoassay of growth hormone-releasing hormone (GHRH) with a polyclonal antibody against synthetic GHRH(129)-Gly ${ }_{4}-\mathrm{Cys}-\mathrm{NH}_{2}$ : method and clinical studies. Clin Chim Acta 202: 243-254.

16. Sano T, Ohshima T, Yamada S (1991) Expression of glycoprotein hormones and intracytoplasmic distribution of cytokeratin in growth hormone-producing pituitary adenomas. Path Res Pract 187: 530-533.

17. Lyons J, Landis CA, Harsh G, Vallar L, Grünewald K, Feichtinger H, Duh QY, Clark OH, Kawasaki E, Bourne HR, McCormick F (1990) Two G protein oncogenes in human endocrine tumors. Science 249: 655-659.

18. Iwasaki H, Stewart PW, Dilley WG, Holt MS, Steinbrueck TD, Wells SA, Donis-Keller H (1992) A minisatellite and microsatellite polymorphism within $1.5 \mathrm{~kb}$ at the human muscle glycogen phos- 
phorylase (PYGM) locus can be amplified by PCR and have combined informativeness of PIC 0.95 . Genomics 13: 7-15.

19. Hauge XY, Evans GA, Litt M (1991) Dinucleotide repeat polymorphism at the D11S534 locus. Nucleic Acids Res 19: 4308.

20. Browne DL, Gault J, Thompson MB, Hauge XY, Evans GA, Litt M (1991) Dinucleotide repeat polymorphism at the D11S527 locus. Nucleic Acids Res 19: 4790 .

21. Weber JL, Kwitek AE, May PE (1990) Dinucleotide repeat polymorphism at the D11S419 and CD3D loci. Nucleic Acids Res 18: 4036.

22. Saiki RK, Scharf S, Faloona F, Mullis KB, Horn GT, Erlich HA, Arnheim N (1985) Enzymatic amplification of $\beta$-globin genomic sequences and restriction analysis for diagnosis of sickle cell anemia. Science 230: 1350-1354.

23. Ziegle JS, Su Y, Corcoran KP, Nie L, Mayrand PE, Hoff LB, McBride LJ, Kronick MN, Diehl SR (1992) Application of automated DNA sizing technology for genotyping microsatellite loci. Genomics 14: 1026-1031.

24. Yoshimoto K, Iwahana H, Fukuda A, Sano T, Saito S, Itakura M (1992) Role of p53 mutations in endocrine tumorigenesis: mutation detection by polymerase chain reaction -single strand conformation polymorphism. Cancer Res 52: 5061-5064.

25. Yoshimoto $K$, Iwahana $H$, Fukuda A, Sano $T$, Katsuragi K, Kinoshita M, Saito S, Itakura M (1992) ras mutations in endocrine tumorigenesis: mutation detection by polymerase chain reaction-single strand conformation polymorphism. Jpn J Cancer Res 83: 1057-1062.

26. Kozasa T, Itoh H, Tsukamoto T, Kaziro Y (1988) Isolation and characterization of the human Gs $\alpha$ gene. Proc Natl Acad Sci USA 85: 2081-2085.

27. Ito H, Toyama R, Kozasa T, Tsukamoto T, Matsuoka M, Kaziro Y (1988) Presence of three distinct molecular species of $\mathrm{Gi}$ protein $\alpha$ subunit: structure of rat cDNAs and human genomic DNAs. J Biol Chem 263: 6656-6664.

28. Hosoi E, Yokogoshi Y, Hosoi E, Yokoi K, Sano T, Saito $S$ (1992) A pituitary specific point mutation of codon 201 of the Gs $\alpha$ gene in a pituitary adenoma of a patient with multiple endocrine neoplasia (MEN) Type 1. Endocrinol Japon 39: 319-324.

29. Lips CJM, Vasen HFA, Lamers CBHW (1984) Multiple endocrine neoplasia syndromes. CRC Critical Reviews in Oncology/Hematology 2: 117-184.

30. Scheithauer BW, Laws Jr ER, Kovacs K, Horvath E, Randall RV, Carney JA (1987) Pituitary adenomas of the multiple endocrine neoplasia type 1 syndrome. Seminars in Diagnostic Pathology 4: 205-211.

31. Frohman LA, Downs TR (1987) Ectopic GRH syndromes In: Robbins RJ, Melmed S (eds) Acromegaly. A Century of Scientific and Clinical Progress. Plenum Publishing, New York: 115-125.

32. Aida M, Furukawa $Y$, Hanyu K, Saito $Y$, Matsuno M, Matoba N, Kimura Y, Miura K, Sato T, Tamahashi N (1977) Familial multiple endocrine neoplasia with a pancreatic carcinoid tumor. Igaku no Ayumi (J Clin Exp Med) 101: 152-159 (In Japanese).

33. Asa SL, Kovacs K, Stefaneanu L, Horvath E, Billestrup N, Gonzalez-Manchon C, Vale W (1992) Pituitary adenomas in mice transgenic for growth hormone-releasing hormone. Endocrinology 131: 2083-2089.

34. Lloyd RV, Jin L, Chang A, Kulig E, Camper SA, Ross BD, Downs TR, Frohman LA (1992) Morphologic effects of hGRH gene expression on the pituitary, liver, and pancreas of MT-hGRH transgenic mice. Am J Pathol 141: 895-906.

35. Fearon ER, Vogelstein B (1990) A genetic model for colorectal tumorigenesis. Cell 61: 759-767.

36. Hosoi E, Yokogoshi Y, Hosoi E, Horie H, Sano T, Yamada S, Saito S (1993) Analysis of Gs $\alpha$ gene in growth hormone-secreting pituitary adenomas by polymerase chain reaction-direct sequencing methed using paraffin-embedded tissues. Eur J Endocrinol 129: 301-306.

37. Yoshimoto K, Iwahana H, Fukuda A, Sano T, Itakura M (1993) Rare mutations of the Gs alfa subunit gene in human endocrine tumors: mutation detection by polymerase chain reaction-primer-introduced restriction analysis. Cancer 72: 1386-1393. 